\title{
The structure-activity relationship review of the main bioactive constituents of Morus genus plants
}

\author{
Jiejing Yan ${ }^{1} \cdot$ Jingya Ruan ${ }^{1} \cdot$ Peijian Huang ${ }^{2} \cdot$ Fan Sun $^{1} \cdot$ Dandan Zheng ${ }^{2} \cdot$ Yi Zhang $^{1,2} \cdot$ Tao Wang $^{1,2}$
}

Received: 12 August 2019 / Accepted: 17 December 2019 / Published online: 2 January 2020

(c) The Author(s) 2020, corrected publication 2020

\begin{abstract}
Morus genus plants are mainly distributed in the temperate to tropical areas over the world and include 17 species and two subspecies. Due to their excellent pharmacological activity, security in food additives and high value in the national economy, Morus genus plants have drawn more and more attention in recent years. In the light of the references published over the last few decades, flavonoids, benzofurans, stilbenes, and Diels-Alder adducts have been reported to be the main bioactive constituents of Morus genus plants. This review summarizes the compounds with excellent bioactivities isolated from Morus genus plants as well as their structure-activity relationships (SARs), which might be useful for the further research and development of Morus genus plants.
\end{abstract}

\section{Graphic abstract}

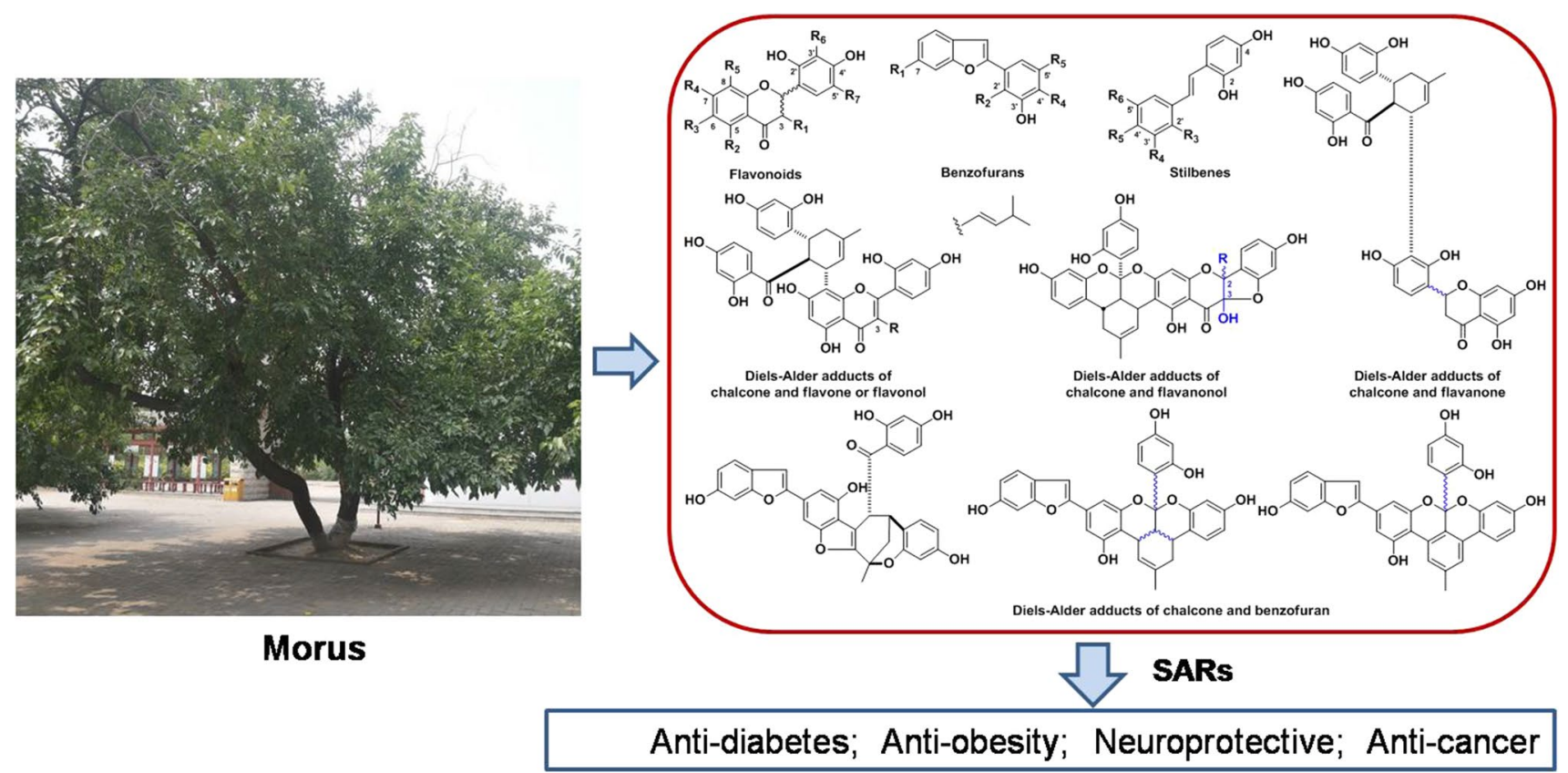

The aromatic heterocycles with excellent bioactivities isolated from Morus genus plants as well as their structure-activity relationships (SARs) were summarized.

Keywords Morus genus plants $\cdot$ Bioactive constituents $\cdot$ Structure-activity relationships

Extended author information available on the last page of the article 


\section{Introduction}

Morus genus plants comprise flowering trees belonging to Moraceae family and are distributed in the temperate to tropical areas over the world. According to the webpage of https://www.theplantlist.org, the Morus genus comprises 17 species and two subspecies. In traditional Chinese medicine (TCM), the leaves, root, bark, stems, and fruits of $M$. alba are used for treatment of rheumatism, cough and inflammation, and the leaves and fruits of $M$. alba serve as foodstuff around the world. Recently, not only $M$. alba, but also other Morus genus plants' (such as M. alba var. tatarica, M. lhou, M. australis, M. yunnanensis, $M$. cathayana, and M. nigra) chemical components and their biological activity have been evaluated [1-3].

Polyphenols, including flavonoids, benzofurans, stilbenes, and Diels-Alder adducts were considered as the main chemical constituents and the key bioactive ingredients of Morus genus plants. Polyphenols from Morus genus plants exhibit multiple bioactivities, such as anti-diabetic, cytotoxicity, hypolipidemic, anti-oxidative, anti-inflammatory, anti-microbial, anti-fungal, skin whitening [4], and neuroprotective effects [5]. Among these, the anti-diabetic effect was confirmed by different clinical research groups [6-9].

This paper intends to provide an review of biological chemical constituents present in Morus genus plants and summarize their structure-activity relationships (SARs) on $\alpha$-glucosidase, lipase, tyrosinase, $\beta$-secretase, acetylcholinesterase and cytotoxicity, which may be benefit for nutritional supplements development and structure modification of lead compound from Morus genus plants.

\section{Polyphenols from Morus genus plants}

Morus genus plants have a diverse polyphenol profile that includes flavonoids, benzofurans, stilbenes, and Diels-Alder adducts with hydroxyl, methoxyl, glycosyl or prenyl substitution moieties as shown as Fig. 1.

Until now, as one of the main ingredients, more than 190 flavonoids were obtained from the leaves $[3,10,11]$ and bark [12,13] of Morus genus plants, which can be grouped into flavone, flavonol, flavanone, flavanonol, and chalcone. Except for chalcones, the hydroxyl and methoxyl groups are usually substituted at C-3, C-5, C-7, C-2', C-3' or C-4', and the glycosylation always occurs at $3-\mathrm{OH}$. In addition, $\mathrm{C}-3$, C-6, C-8, C-3' or C-5' are usually substituted by prenyl and its analogs. Sometimes, the prenyl unit at C- 6 and $\mathrm{C}-8$ are cyclized with 5-OH and 7-OH, respectively.

For benzofurans from Morus genus plants, the major substitution type is hydroxyl or methoxyl at C-7, C-3' or
C-5', while the prenyl group substitution often occurs at C-7, C-2' and C-4', and the cyclization is always linked between 4 '-prenyl and $3^{\prime}-\mathrm{OH}$.

Stilbenes, whose chemical structures are similar to those of benzofurans, are another kind of compounds in Morus genus plants. The substitution types and positions are similar to those of benzofurans. According to the different numbering rules, the oxygen groups at $\mathrm{C}-2, \mathrm{C}-4, \mathrm{C}-3^{\prime}$ and $\mathrm{C}-5^{\prime}$ and prenyl groups at $\mathrm{C}-2^{\prime}$ and $\mathrm{C}-4^{\prime}$ have the most common substitution patterns.

Diels-Alder adducts are another kind of polyphenols in Morus genus plants, most of them contain flavonoid groups, and the $\mathrm{C}-2$ and $\mathrm{C}-3$ of the flavonoid unit can be replaced by prenyls and their analogs.

\section{SARs of bioactive compounds from Morus genus plants}

As a widely used complementary and alternative medicine, Morus genus plants, especially mulberry leaves, were used as adjuvant for blood sugar and TG management, neuroprotection, as anti-tumor agent, immunity regulation, and so on. According to their clinic effects, bioactive compounds in Morus genus plants were screened and the SARs to key enzymes partly characterized.

\section{SARs of a-glucosidase inhibition}

Type 2 diabetes is a kind of metabolic disease affecting more and more people all over the world. It is characterized by high postprandial glucose level, high fasting glucose level, insulin resistance, and relative lack of insulin. As one of the effective treatments for high postprandial glucose level, $\alpha$-glucosidase inhibitors were used to lower the digestion of carbohydrates and reduce the absorption of glucose from the intestine $[12,14]$. 1-Deoxynojirimycin and its analogs obtained from leaves of Morus genus plants have been considered to be a classical effective $\alpha$-glucosidase inhibitor [7, 8], and flavonoids, benzofurans and Diels-Alder adducts were also found to play significant roles.

Diels-Alder adducts of chalcones with benzofurans or stilbenes [morusalbins A-D (1-4), albanol B (5), and mulberrofuran $\mathrm{G}(6)\left(\mathrm{IC}_{50}\right.$ values: $4.5 \pm 0.3,5.1 \pm 0.3,5.4 \pm 0.4$, $3.6 \pm 0.0,4.3 \pm 0.0,2.3 \pm 0.2$, respectively] obtained from the root bark of $M$. alba proved to be more effective than those of flavonoids and benzofurans [albanins A (7) and C (9), kuwanon C (8), albanin T (10), moracins M (11), S (12), mulberrofuran $\mathrm{L}(\mathbf{1 3})\left(\mathrm{IC}_{50}\right.$ values: $40.5 \pm 5.1,11.8 \pm 0.3$, $16.9 \pm 2.1,35.4 \pm 0.4,16.5 \pm 1.0,13.5 \pm 1.1,10.8 \pm 0.6 \mu \mathrm{M}$, respectively)] on $\alpha$-glucosidase (enzyme: from yeast; substrate: $p$-nitrophenyl $\alpha$-D-glucopyranoside) [12]. 
<smiles>[R]Cc1cc([C@H]2Oc3c([R5])c([R])c([R3])c([R2])c3C(=O)C2[R7])c([R])c([R])c1[R6]</smiles>

Flavonoids<smiles>[R]c1c(-c2ccc(O)cc2O)oc2c([C@@H]3C=C(C)C[C@H](c4ccc(O)cc4O)[C@H]3C(=O)c3ccc(O)cc3O)c(O)cc(O)c2c1=O</smiles>

Diels-Alder adducts of chalcone and flavone or flavonol<smiles>[R]c1ccc2cc(-c3cc([R5])c([R4])c([R])c3[R])oc2c1</smiles>

Benzofurans<smiles>[R]c1ccc(/C=C/c2cc([R])c([R5])c([R4])c2[R3])c([R])c1</smiles>

Stilbenes<smiles>CC1=C[C@H](C)[C@H](C(=O)c2ccc(O)cc2O)[C@H](c2ccc(O)cc2O)C1</smiles>

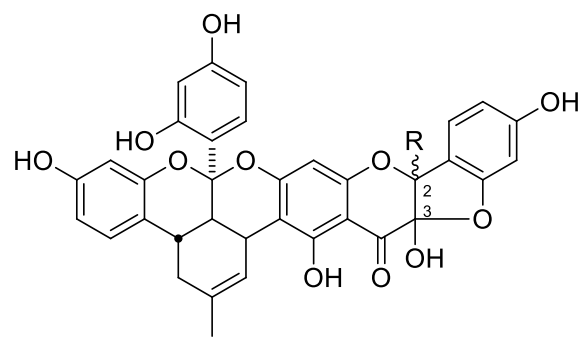

Diels-Alder adducts of chalcone and flavanonol<smiles>Cc1c(O)ccc([C@H]2CC(=O)c3c(O)cc(O)cc3O2)c1O</smiles>

Diels-Alder adducts of chalcone and flavanone<smiles></smiles>

Diels-Alder adducts of chalcone and benzofuran

$$
\xi-\mathrm{OH} \quad \xi-\mathrm{OCH}_{3}
$$

Hydroxyl

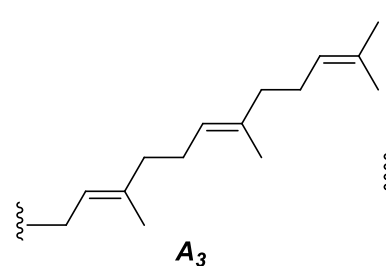

(Faenesyl)

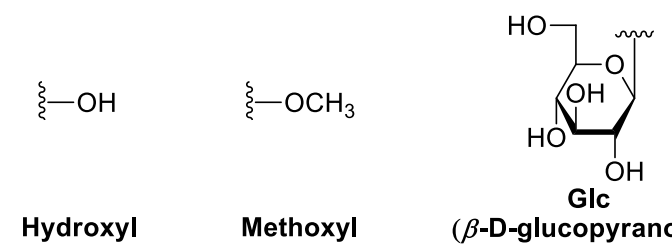

syl)

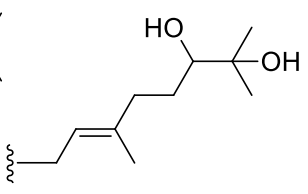

$A_{4}$

((E)-2,6-Dimethyl6-octene-2,3-diol)<smiles>OC1OC2C(O)C1OC1C(O)C2C1O</smiles>

Rha<smiles>CCC=C(C)C</smiles>

$A_{1}$ (Prenyl)

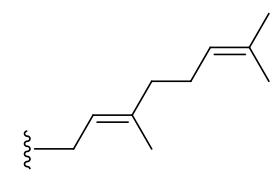

$A_{2}$ (Geranyl)

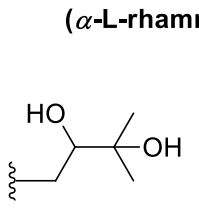

$A_{5}$<smiles>C=C1CCC(O)C(C)(C)C1CCC</smiles>

$A_{6}$

(2-Methyl-2,3- (6,6-Dimethyl-5-hydroxyl-2- (exo-1,2,3,3-tetramethyl-7butanediol) methylenecyclohexylmethyl) Oxabicyclo[2.2.1]heptane)

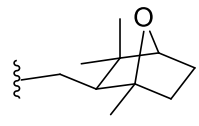

$A_{7}$

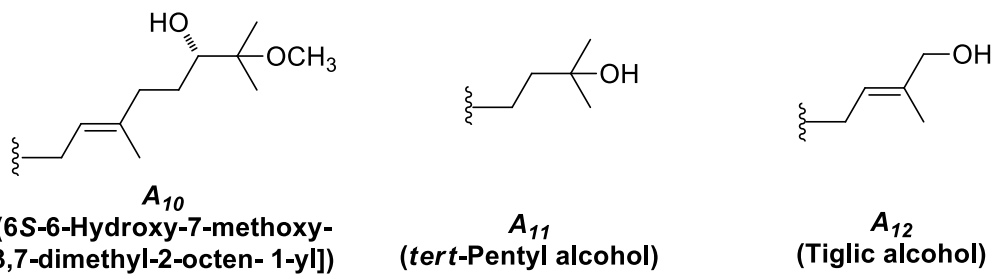

Fig. 1 Characteristic structure of compounds from Morus genus plants and structural moieties 
Comparing the activities of flavonoids, it was suggested that their $\alpha$-glucosidase inhibitory abilities were influenced by the substitution of prenyl and hydroxyl groups [12, 15]. The SARs were summarized as follows: (1) prenyl group substitution enhanced the activities [kuwanons $\mathrm{C}(\mathbf{8})$ and $\mathrm{T}$ (14) vs albanin A (7) isolated from the root bark of $M$. alba var. tatarica, with $\mathrm{IC}_{50}$ values at $16.9 \pm 2.1,12.7 \pm 1.9$, and $40.5 \pm 5.1 \mu \mathrm{M}$, respectively)] (enzyme: from yeast; substrate: $p$-nitrophenyl $\alpha$-D-glucopyranoside) [15]. The cyclization of the prenyl group reduced the activities ( 7 and 8 vs 15) (15 was inactive) [15]. (2) Hydroxyl substitution located at C-2' of the flavonoid aglycon could enhance the activity on $\alpha$-glucosidase inhibition [albanin D (16) vs albanin E (17) isolated from the root bark of M. alba var. tatarica with $\mathrm{IC}_{50}$ values at $11.5 \pm 0.7$ and $5.9 \pm 0.2$, respectively] [15], which could also be proved by the activity determination results of norartocarpetin (18), kaempferol (19), and quercetin (20) from leaves of $M$. alba $\left(\mathrm{IC}_{50}\right.$ values of $13.4 \pm 0.6,33.7 \pm 0.7$, and $19.6 \pm 2.4 \mu \mathrm{M}$, respectively) (enzyme: from yeast; substrate: $p$-nitrophenyl $\alpha$-D-glucopyranoside) [16]. While the hydroxylation of prenyl might decrease the inhibitory activities of prenyl substituted flavonoids [albanin D (16, $\left.\mathrm{IC}_{50} 5.9 \pm 0.2 \mu \mathrm{M}\right)$ vs mortatarin $\mathrm{C}$ (21, inactive); kuwanon $\mathrm{C}\left(\mathbf{8}, \mathrm{IC}_{50} 16.9 \pm 2.1 \mu \mathrm{M}\right)$ vs mortatarin $\mathrm{B}(\mathbf{2 2}$, inactive $)$ from the root bark of M. alba var. tatarica] [15] (Fig. 2).

Benzofurans from Morus genus plants also showed $\alpha$-glucosidase inhibitory effect [17]. 4'-(6,6-dimethyl- 5 - hy droxyl-2 - methylenecyclohexylmethyl)$3^{\prime}, 5^{\prime}, 6$-trihydroxy-2-arylbenzofuran (23), 4'-(6-hydroxy-3,7-di-methyl-2,7-octadien-1-yl)-3',5',6trihydroxy-2-arylbenzofuan (24), 4'-(6,7-dihydroxy-3,7dimethyl-2-octen-1-yl)-3',5',6-trihydroxy-2-arylbenzofuan (25), 2'-(1,3,3-trimethyl-7-oxabicyclo[2.2.1]hept-2ylmethyl)-3'-methoxy-5',6-dihydroxy-2-arylbenzofuran (26), (7' $R$ )-2'-(6-hydroxy-3,7-dimethyl-2,7-octadien1 -yl)-3'-methoxy-5',6-dihydroxy-2-arylbenzofuran (27), (7' $S$ )-2'-(6-hydroxy-3,7-dimethyl-2,7-octadien1 -yl)-3'-methoxy-5',6-dihydroxy-2-arylbenzofuran (28), 2'-(6,7-dihydroxy-3,7-dimethyl-2-octen-1-yl)3',5',6-trihydroxy-2-arylbenzofuan (29), 2'-(6,7-dihy droxy-3,7-dimethyl-2-octen-1-yl)-3'-methoxy$5^{\prime}, 6$-dihydroxy-2-arylbenzofuran (30), and $2^{\prime}$-[(6S)-6-hydroxy-7-methoxy-3,7-dimethyl-2-octen-1-yl]3'-methoxy-5',6-dihydroxy-2-arylbenzofuran (31) were isolated from the root bark of $M$. alba var. tatarica. The $\mathrm{IC}_{50}$ values were $11.9 \pm 1.3,33.1 \pm 1.9,29.5 \pm 3.4,21.5 \pm 0.5$, $85.3 \pm 2.7,67.2 \pm 3.2,21.9 \pm 1.7,101.5 \pm 6.5$ and $>150 \mu \mathrm{M}$, respectively (enzyme: from yeast; substrate: $p$-nitrophenyl $\alpha$-D-glucopyranoside). The activity differences between them suggested that the substitution types of prenyl groups were important for $\alpha$-glucosidase inhibitory effcts. Meanwhile, hydroxyl at C-3' might be another functional group of benzofurans (29 vs 30). The abnormal behavior of $\mathbf{2 6}$ might be caused by the effect of the side chain (Fig. 2).

\section{SARs of lipase inhibition}

Hyperlipemia is a high risk factor of obesity, heart disease, diabetes and retinal vascular disease with an abnormally high triglyceride (TG) level in the blood. Pancreatic lipase (PL) is an enzyme that catalyzes triglyceride to fatty acids and glycerol. Inhibition of PL can decrease TG hydrolysis and reduce free fatty acid absorption from intestine to blood and finally lower blood TG level [18, 19]. Orlistat, a PL inhibitor, was used as an anti-obesity drug to inhibit dietary fat absorption and reduce cardiovascular risk factors.

Several flavonoids and benzofurans obtained from Morus genus plants were reported to be PL inhibitors. Jeong et al. reported that the PL-inhibitory activities of both flavonols and flavanones from the leaves of $M$. alba would be decreased by the substitution of hydroxyl [kaempferol (19) > quercetin (20), 7,2',4'-trihydroxyflavanone (32) > steppogenin (33)], the activities could also be reduced by glycosylation [quercetin (20) > quercetin-3-O-glucopyranoside (34)] (enzyme: porcine pancreatic lipase; substrate: $p$-nitrophenylbutyrate) [20].

For 2-arylbenzofurans from the leaves of $M$. alba, the hydroxylation could enhance the PL-inhibitory activities [2-(3,5-dihydroxyphenyl)-5,6-dihydroxybenzofuran (35) and wittifuran $\mathrm{E}(\mathbf{3 6})>$ moracin $\mathrm{M}$ (37)]. Moreover, the prenyl group may also be an active unit in PL inhibition [moracins $\mathrm{N}(\mathbf{3 8})$ and $\mathrm{C}(\mathbf{3 9})>\mathbf{3 5}-\mathbf{3 7}$ and albafuran $\mathrm{A}(\mathbf{4 0})$ ] [20] (Fig. 3). According to Ha et al. report, compounds isolated from the root bark of $M$. alba, morusalfurans B (41) and C (42), mulberrofuran D (43), and sanggenofuran A (44) showed inhibitory effect on PL ( $\mathrm{IC}_{50}$ values: 0.4, 0.6, 0.1 , and $0.9 \mu \mathrm{M}$, respectively) (enzyme: porcine pancreatic lipase; substrate: $p$-nitrophenylbutyrate) [21]. Through the observation of the structures of bioactive compounds, it was found that if $3^{\prime}-\mathrm{OH}$ in 2-arylbenzofurans were methylated, their PL inhibitory activity may be decreased (41 vs 42,43 vs 44) (Fig. 3).

\section{SARs of tyrosinase inhibition}

Tyrosinase is an oxidase distributed in fungi, plants and animals widely. Generally, tyrosinase is known to be involved in melanin synthesis that gives skin, hair, and eyes color. In tumor cells, tyrosinase expression level is significantly upregulated than in normal cells along with increase of tyrosinase activity. Tyrosinase inhibitors have attracted considerable attention in improving tumor immunity, such as imatinib, an antitumor drug against chronic myelogenous leukemia.

Morus genus plants-enriched polyphenol had been used as a kind of non-toxic natural tyrosinase inhibitor to whiten 


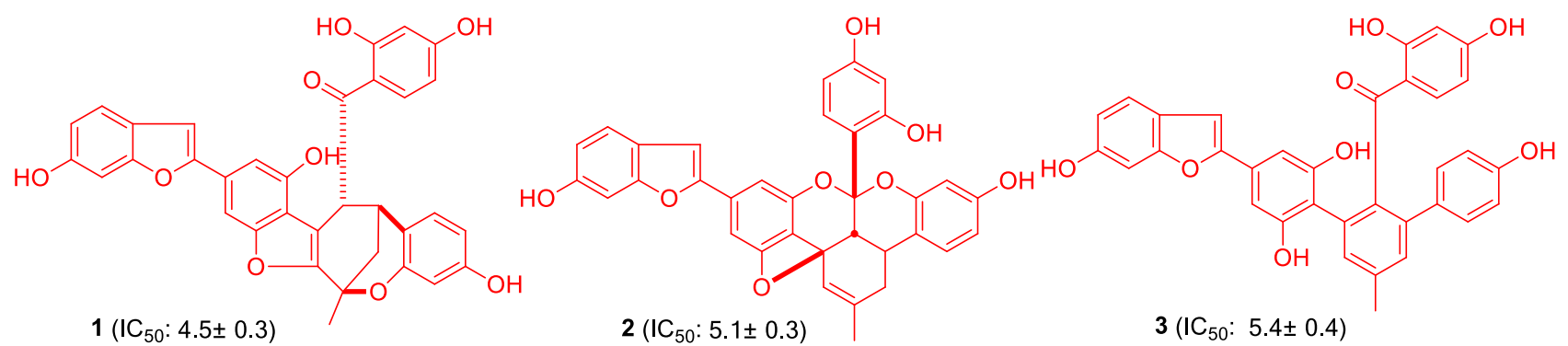

$1\left(\mathrm{IC}_{50}: 4.5 \pm 0.3\right)$

$2\left(\mathrm{IC}_{50}: 5.1 \pm 0.3\right)$

$3\left(\mathrm{IC}_{50}: 5.4 \pm 0.4\right)$

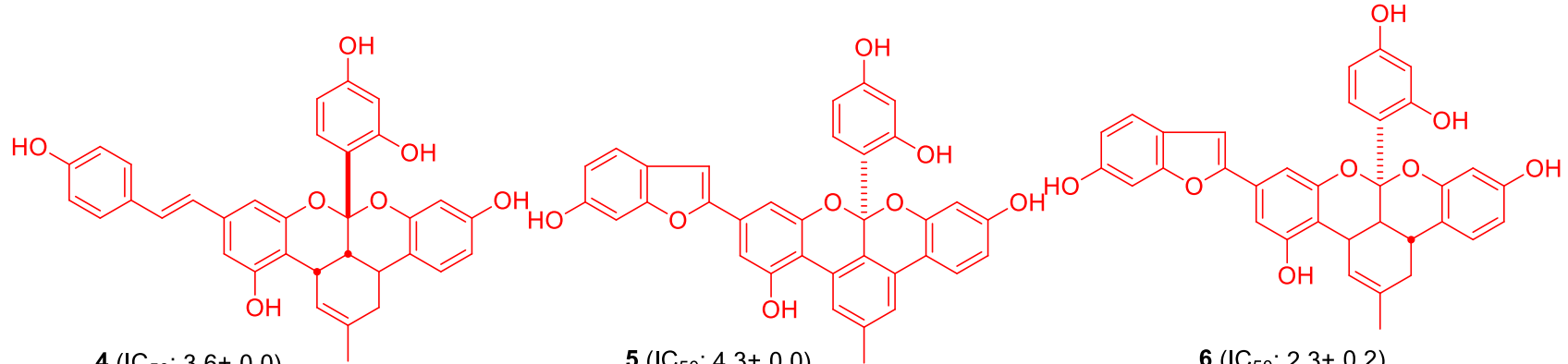
$4\left(\mathrm{IC}_{50}: 3.6 \pm 0.0\right)$

$5\left(\mathrm{IC}_{50}: 4.3 \pm 0.0\right)$

$6\left(\mathrm{IC}_{50}: 2.3 \pm 0.2\right)$<smiles>[R]c1c(O)ccc(-c2oc3c([R])c(O)c([R])c(O)c3c(=O)c2[R])c1[R]</smiles>

\begin{tabular}{rcccccc} 
& $\mathrm{R}_{1}$ & $\mathrm{R}_{2}$ & $\mathrm{R}_{3}$ & $\mathrm{R}_{4}$ & $\mathrm{R}_{5}$ & $\mathrm{IC}_{50}$ \\
\cline { 2 - 6 } 7: & $\boldsymbol{A}_{\mathbf{1}}$ & $\mathrm{H}$ & $\mathrm{H}$ & $\mathrm{OH}$ & $\mathrm{H}$ & $40.5 \pm 5.1$ \\
8: & $\mathrm{A}_{1}$ & $\mathrm{H}$ & $\mathrm{A}_{1}$ & $\mathrm{OH}$ & $\mathrm{H}$ & $16.9 \pm 2.1$ \\
14: & $\mathrm{A}_{1}$ & $\mathrm{H}$ & $\mathrm{H}$ & $\mathrm{OH}$ & $\mathrm{A}_{1}$ & $12.7 \pm 1.9$ \\
16: & $\mathrm{H}$ & $\boldsymbol{A}_{\mathbf{2}}$ & $\mathrm{H}$ & $\mathrm{H}$ & $\mathrm{H}$ & $11.5 \pm 0.7$ \\
17: & $\mathrm{H}$ & $\boldsymbol{A}_{2}$ & $\mathrm{H}$ & $\mathrm{OH}$ & $\mathrm{H}$ & $5.9 \pm 0.2$ \\
18: & $\mathrm{H}$ & $\mathrm{H}$ & $\mathrm{H}$ & $\mathrm{OH}$ & $\mathrm{H}$ & $13.4 \pm 0.6$ \\
19: & $\mathrm{OH}$ & $\mathrm{H}$ & $\mathrm{H}$ & $\mathrm{H}$ & $\mathrm{H}$ & $33.7 \pm 0.7$ \\
20: & $\mathrm{OH}$ & $\mathrm{H}$ & $\mathrm{H}$ & $\mathrm{H}$ & $\mathrm{OH}$ & $19.6 \pm 2.4$ \\
21: & $\mathrm{H}$ & $\boldsymbol{A}_{\mathbf{4}}$ & $\mathrm{H}$ & $\mathrm{H}$ & $\mathrm{H}$ & Inactive \\
22: & $\boldsymbol{A}_{\mathbf{1}}$ & $\mathrm{H}$ & $\boldsymbol{A}_{\mathbf{4}}$ & $\mathrm{OH}$ & $\mathrm{H}$ & Inactive \\
\hline & & & & & &
\end{tabular}<smiles>CC(C)=CCc1c(-c2ccc(O)cc2O)oc2c3c(cc(O)c2c1=O)OC(C(C)(C)O)C3</smiles>

$9\left({ }^{\prime} C_{50}: 11.8 \pm 0.3\right)$<smiles>CC(C)=CCc1c(-c2ccc(O)c3c2OC(C(C)(C)O)C3)oc2cc(O)cc(O)c2c1=O</smiles>

$10\left(\mathrm{IC}_{50}: 35.4 \pm 0.4\right)$<smiles>CC(C)=CCc1c(-c2ccc(O)cc2O)oc2c3c(cc(O)c2c1=O)OC(C)(C)C=C3</smiles><smiles>[R]c1c(O)cc(-c2cc3ccc(O)c([R])c3o2)c([R3])c1[R]</smiles>

\begin{tabular}{lccccc} 
& $\mathrm{R}_{1}$ & $\mathrm{R}_{2}$ & $\mathrm{R}_{3}$ & $\mathrm{R}_{4}$ & $\mathrm{IC}_{50}$ \\
\cline { 2 - 6 } 11: & $\mathrm{H}$ & $\mathrm{H}$ & $\mathrm{OH}$ & $\mathrm{H}$ & $16.5 \pm 1.0$ \\
12: & $\boldsymbol{A}_{1}$ & $\mathrm{H}$ & $\mathrm{OH}$ & $\mathrm{H}$ & $13.5 \pm 1.1$ \\
13: & $\boldsymbol{A}_{2}$ & $\mathrm{H}$ & $\mathrm{OH}$ & $\mathrm{H}$ & $10.8 \pm 0.6$ \\
23: & $\mathrm{H}$ & $\mathrm{H}$ & $\mathrm{OH}$ & $\boldsymbol{A}_{5}$ & $11.9 \pm 1.3$ \\
24: & $\mathrm{H}$ & $\mathrm{H}$ & $\mathrm{OH}$ & $\boldsymbol{A}_{6}$ & $33.1 \pm 1.9$ \\
25: & $\mathrm{H}$ & $\mathrm{H}$ & $\mathrm{OH}$ & $\boldsymbol{A}_{3}$ & $29.5 \pm 3.4$ \\
26: & $\mathrm{H}$ & $\boldsymbol{A}_{7}$ & $\mathrm{OCH}_{3}$ & $\mathrm{H}$ & $21.5 \pm 0.5$ \\
27: & $\mathrm{H}$ & $\boldsymbol{A}_{8}$ & $\mathrm{OCH}_{3}$ & $\mathrm{H}$ & $85.3 \pm 2.7$ \\
28: & $\mathrm{H}$ & $\boldsymbol{A}_{9}$ & $\mathrm{OCH}_{3}$ & $\mathrm{H}$ & $67.2 \pm 3.2$ \\
29: & $\mathrm{H}$ & $\boldsymbol{A}_{3}$ & $\mathrm{OH}^{\mathrm{O}}$ & $\mathrm{H}$ & $21.9 \pm 1.7$ \\
30: & $\mathrm{H}$ & $\boldsymbol{A}_{3}$ & $\mathrm{OCH}_{3}$ & $\mathrm{H}$ & $101.5 \pm 6.5$ \\
31: & $\mathrm{H}$ & $\boldsymbol{A}_{10}$ & $\mathrm{OCH}_{3}$ & $\mathrm{H}$ & $>150$ \\
\hline & & & & &
\end{tabular}

\section{SARs study of $\alpha$-glucosidase inhibitory activity}

1. Diels-Alder adducts of chalcones with benzofurans or stilbenes were more effective than flavonoids and benzofurans (1-6 $>$ 7-13);

2. Prenyl group substitution enhanced the activities $(8,14>7)$;

3. 2 - $-\mathrm{OH}$ substitution enhanced the activities of flavonoid $(17>16)$;

4. Cyclization of prenyl group reduced the activities $(15<7,8)$;

5. Hydroxylation of prenyl decrease the activities of prenyl substituted flavonoids $(21<16 ; 22<8)$;

6 . 3 '-methylation decrease the activities of benzofurans $(30<29)$

Fig. 2 Structures of compounds 1-31 (the structure of $\boldsymbol{A}_{\mathbf{1}}-\boldsymbol{A}_{10}$ see Fig. 1) for SARs study of $\alpha$-glucosidase inhibitory activity (the unit of IC ${ }_{50}$ : $\mu \mathrm{M})$ 
<smiles>[R7]Oc1c(-c2ccc(O)c([R3])c2[R2])oc2cc(O)cc(O)c2c1=O</smiles>

\begin{tabular}{|c|c|c|c|}
\hline $\mathrm{R}_{1}$ & $\mathrm{R}_{2}$ & $\mathrm{R}_{3}$ & PL inhibition (\%) \\
\hline $\mathrm{H}$ & $\mathrm{H}$ & $\mathrm{H}$ & $50.3 \pm 3.7$ \\
\hline : $\mathrm{H}$ & $\mathrm{OH}$ & $\mathrm{OH}$ & $36.3 \pm 6.3$ \\
\hline$: \mathrm{Glc}$ & $\mathrm{OH}$ & $\mathrm{OH}$ & $12.6 \pm 4.8$ \\
\hline
\end{tabular}<smiles>[R]c1cc(O)cc2c1C(=O)C[C@@H](c1ccc(O)cc1O)O2</smiles><smiles>[R]c1cc2cc(-c3c([R])c([R6])c([R5])c(O)c3[R])oc2c([R2])c1O</smiles>

\begin{tabular}{lccccccc} 
& $\mathrm{R}_{1}$ & $\mathrm{R}_{2}$ & $\mathrm{R}_{3}$ & $\mathrm{R}_{4}$ & $\mathrm{R}_{5}$ & $\mathrm{R}_{6}$ & PL inhibition (\%) \\
\cline { 2 - 7 } 35: & $\mathrm{H}$ & $\mathrm{OH}$ & $\mathrm{H}$ & $\mathrm{H}$ & $\mathrm{H}$ & $\mathrm{H}$ & $59.1 \pm 5.3$ \\
36: & $\mathrm{OH}$ & $\mathrm{H}$ & $\mathrm{H}$ & $\mathrm{H}$ & $\mathrm{H}$ & $\mathrm{H}$ & $55.9 \pm 3.9$ \\
37: & $\mathrm{H}$ & $\mathrm{H}$ & $\mathrm{H}$ & $\mathrm{H}$ & $\mathrm{H}$ & $\mathrm{H}$ & $21.5 \pm 4.6$ \\
38: & $\mathrm{A}_{1}$ & $\mathrm{H}$ & $\mathrm{H}$ & $\mathrm{H}$ & $\mathrm{H}$ & $\mathrm{H}$ & $61.7 \pm 6.2$ \\
39: & $\mathrm{H}$ & $\mathrm{H}$ & $\mathrm{H}$ & $\mathrm{H}$ & $\mathrm{A}_{1}$ & $\mathrm{H}$ & $64.8 \pm 7.2$ \\
40: & $\mathrm{H}$ & $\mathrm{H}$ & $c i s-\boldsymbol{A}_{\mathbf{2}}$ & $\mathrm{H}$ & $\mathrm{H}$ & $\mathrm{H}$ & $45.4 \pm 6.3$ \\
& & & & & & & $\mathrm{IC}_{50}(\mu \mathrm{M})$ \\
41: & $\mathrm{H}$ & $\mathrm{H}$ & $\boldsymbol{A}_{\mathbf{3}}$ & $\mathrm{H}$ & $\mathrm{H}$ & $\boldsymbol{A}_{\mathbf{1}}$ & 0.4 \\
42: & $\mathrm{H}$ & $\mathrm{H}$ & $\boldsymbol{A}_{\mathbf{3}}$ & $\mathrm{CH}_{3}$ & $\mathrm{H}$ & $\mathrm{H}$ & 0.6 \\
43: & $\mathrm{H}$ & $\boldsymbol{A}_{\mathbf{2}}$ & $\boldsymbol{A}_{\mathbf{1}}$ & $\mathrm{H}$ & $\mathrm{H}$ & $\mathrm{H}$ & 0.1 \\
44: & $\mathrm{H}$ & $\boldsymbol{A}_{\mathbf{2}}$ & $\boldsymbol{A}_{\mathbf{1}}$ & $\mathrm{CH}_{3}$ & $\mathrm{H}$ & $\mathrm{H}$ & 0.9
\end{tabular}

\section{SARs study of lipase inhibitory activity}

1. Hydroxylation enhanced the activities of 2-arylbenzofurans $(35,36>37)$;

2. Prenylation enhanced the activities of benzofurans $(38,39>35-37,40)$;

3. Hydroxylation or glycosylation decreased the activities of flavonoids $(20<19 ; 33<32 ; 34<20)$

4. 3'-methylation decreased the activities of 2-arylbenzofurans $(\mathbf{4 2}<\mathbf{4 1} ; \mathbf{4 4}<\mathbf{4 3})$

Fig. 3 Structures of compounds 19, 20, and 32-44 (the structure of $\boldsymbol{A}_{1}-\boldsymbol{A}_{3}$ see Fig. 1) for SARs study of lipase inhibitory activity. Relative PL inhibition (\%) was calculated as 100 - (activity of sample

skin [22, 23]. Early in 1998, Shin et al. [24] have studied the tyrosinase inhibitory activity of the hydroxystilbenes isolated from the twig of M. alba. The SARs summarized in the reference suggested that the existence of hydroxyl groups in oxyresveratrol and their positions might be important for its inhibitory activity, and the substitution of methyl groups would negatively influence the inhibitory effects. Moreover, Zheng et al. [25] have reported that the substituted position of prenyl/geranyl groups is the key moiety in the tyrosinase inhibitory activity of flavonoids from roots of Morus nigra, monoisoprenyl-substituted flavone compounds as well as 2 -arylbenzofuran derivatives. Free hydroxyl group may be the active unit, especially for 4'-OH of flavanone, 2- or 4-OH of stilbenes and 4-OH resorcinol skeleton. Intact prenyl group might lead to higher tyrosinase inhibitory activity.

Prenyl flavonoids, kuwanon C (8), morusin (15), norartocarpetin (18), mormin (45), and cyclomorusin (46) isolated from the stem barks of $M$. lhou were found to show tyrosinase inhibitory activities with the $\mathrm{IC}_{50}$ values of with substrate-negative control of sample without substrate)/(activity of without sample and with substrate-negative control of without sample and substrate) $\times 100 \%$

$135,250,>2500,88$, and $92 \mu \mathrm{M}$, respectively (enzyme: from mushroom; substrate: L-tyrosine). On comparing their activities, it could be found that the prenyl group might be a crucial active unit ( $\mathbf{8}$ vs $\mathbf{1 8}$ ), and the cyclization of prenyl may lower the inhibitory effects ( 8 vs 15). Moreover, hydroxyl substitution at the prenyl group leads to enhancing the inhibition effect $(\mathbf{4 5}, \mathbf{4 6}$ vs $8, \mathbf{1 5})$ (enzyme: from mushroom; substrate: L-tyrosine) [26] (Fig. 4).

The comparison of the activities of kuwanon $G(47)$ and moracenin D (48) with kuwanon L (49) from the roots of $M$. australis indicated that the prenyl groups may not be the key active units of a Diels-Alder adduct of chalcone with flavonoid, though the type of prenyl groups would influence the tyrosinase inhibitory activity. When the prenyl group was hydroxylated, a higher inhibition effect appeared $\left(\mathrm{IC}_{50}\right.$ values: $>200,4.6 \pm 0.1$, and $58.8 \pm 1.5 \mu \mathrm{M}$ for 47, 48, and 49, respectively) (enzyme: from mushroom; substrate: L-tyrosine) [27] (Fig. 4). 
<smiles>[R]c1c(-c2ccc(O)cc2O)oc2c([R2])c(O)cc(O)c2c1=O</smiles><smiles>[R2]CC1(C)C=Cc2c(cc(O)c3c(=O)c([R])c(-c4ccc(O)cc4O)oc23)O1</smiles>

\begin{tabular}{cccc} 
& $\mathrm{R}_{1}$ & $\mathrm{R}_{2}$ & $\mathrm{IC}_{50}$ \\
\cline { 2 - 4 } 45: & $\boldsymbol{A}_{\boldsymbol{1}}$ & $\mathrm{H}$ & 250 \\
$\boldsymbol{A}_{\mathbf{1 1}}$ & $\mathrm{OH}$ & 88 \\
\hline
\end{tabular}<smiles>CC(C)=CC1Oc2cc(O)ccc2-c2oc3c4c(cc(O)c3c(=O)c21)OC(C)(C)C=C4</smiles><smiles>[R]c1c(-c2ccc(O)cc2O)oc2c([C@@H]3C=C(C)C[C@H](c4ccc(O)cc4O)[C@H]3C(=O)c3ccc(O)cc3O)c(O)cc(O)c2c1=O</smiles>

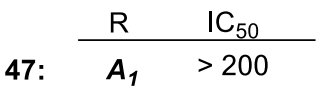

48: $\quad A_{12} \quad 4.6 \pm 0.1$<smiles>CC1=C[C@H](Cc2c(O)ccc(C3CC(=O)c4c(O)cc(O)cc4O3)c2O)[C@H](C(=O)c2ccc(O)cc2O)[C@H](c2ccc(O)cc2O)C1</smiles>

$49\left(\mathrm{IC}_{50}: 58.8 \pm 1.5\right)$

\section{SARs study of tyrosinase inhibitory activity}

1. Prenylation might make the activity stronger $(8>18)$;

2. Hydroxyl substitution at prenyl group may enhance inhibition effect $(45,46>8,15 ; 47>48)$;

3. Cyclization of prenyl may lower the inhibitory effects $(\mathbf{1 5}<\mathbf{8})$

Fig. 4 Structures of compounds $8, \mathbf{1 5}, \mathbf{1 8}$, and $\mathbf{4 5 - 4 9}$ (for the structure of $\boldsymbol{A}_{1}, \boldsymbol{A}_{11}$, and $\boldsymbol{A}_{\mathbf{1 2}}$ see Fig. 1) for SARs study of tyrosinase inhibitory activity (the unit of $\mathrm{IC}_{50}: \mu \mathrm{M}$ )

\section{SARs of $\beta$-secretase and acetylcholinesterase inhibition}

Alzheimer's disease (AD) is a neurodegenerative disease that is characterized by memory impairment and loss of recognition, with neuropathological changes such as cerebral $\beta$-amyloid angiopathy, neurofibrillary tangles, and glial responses [5, 28].

$\beta$-Secretase (BACE) is an integral membrane aspartyl protease that initiates the production of amyloid protein and plays a crucial role in $\mathrm{AD}$ occurrence and development. BACE inhibitor can prevent the buildup of $\beta$-amyloid and show benefits to AD therapy.

Cho et al. [29] reported the inhibitory effects on human BACE-1 (substrate: oligopeptide) of eight compounds obtained from the stem bark of M. lhou, and the SARs suggested that the prenyl groups in flavones and the hydroxyl in ring B played an important role in the BACE-1 inhibitory activities.

A significant feature in the $\mathrm{AD}$ brain is the high level of acetylcholinesterase (AChE) associated with $\beta$-amyloid plaques. AChE, a key enzyme in cholinergic transmission, promotes the hydrolysis of acetylcholine. AChE inhibitor, such as donepezil, is primarily used to keep acetylcholine levels as high as possible despite cell damage and destruction, to treat memory and learning deficit symptoms.

Four kinds of flavonoids, 5'-geranyl-5,7,2',4'tetrahydroxyflavone (50) and 5'-geranyl-4'-methoxy-5,7,2'trihydroxyflavone (51), together with kuwanons E (52) and $\mathrm{U}$ (53) obtained from the root bark of $M$. lhou were reported to possess AChE inhibitory activities using acetylthiocholine iodide as substrate, while kuwanon C (8), morusin (15), cyclomorusin (46), morusinol (54), and neocyclomorusin (55) were inactive [30]. The results indicated that geranyl substituted at C-5' in the ring B may be crucial for the inhibitory effects of flavonoids or 3,8-diprenylation reduced the activity (Fig. 5). In addition, glycosylation could reduce the protective effects of glutamate-induced oxidative injury in mouse hippocampal HT22 cells [quercetin (20) vs isoquercetin (34); $\mathrm{EC}_{50}$ values: $37.2 \pm 3.6,>80 \mu \mathrm{M}$ for 20, 34, respectively] [31] (Fig. 5).

\section{Cytotoxicity}

Compounds obtained from the Morus species, especially prenylated phenols, exhibited significant cell growth inhibition in various cancer cells. The cytotoxic properties against murine leukemia P-388 cells for kuwanon C (8), 
<smiles>[R]c1cc(-c2oc3c([R])c(O)cc(O)c3c(=O)c2[R])c([R])c([R])c1[R]</smiles>

\begin{tabular}{rccccccc} 
& $\mathrm{R}_{1}$ & $\mathrm{R}_{2}$ & $\mathrm{R}_{3}$ & $\mathrm{R}_{4}$ & $\mathrm{R}_{5}$ & $\mathrm{R}_{6}$ & $\mathrm{EC}_{50}$ \\
\cline { 2 - 7 } 20: & $\mathrm{OH}$ & $\mathrm{H}$ & $\mathrm{H}$ & $\mathrm{OH}$ & $\mathrm{OH}$ & $\mathrm{H}$ & $37.2 \pm 3.6$ \\
34: & $\mathrm{OGlC}$ & $\mathrm{H}$ & $\mathrm{H}$ & $\mathrm{OH}$ & $\mathrm{OH}$ & $\mathrm{H}$ & $>80$ \\
& & & & & & & $\mathrm{IC}_{50}$ \\
8: & $\boldsymbol{A}_{1}$ & $\boldsymbol{A}_{1}$ & $\mathrm{OH}$ & $\mathrm{H}$ & $\mathrm{OH}$ & $\mathrm{H}$ & Inactive \\
50: & $\mathrm{H}$ & $\mathrm{H}$ & $\mathrm{OH}$ & $\mathrm{H}$ & $\mathrm{OH}$ & $A_{2}$ & 16.2 \\
51: & $\mathrm{H}$ & $\mathrm{H}$ & $\mathrm{OH}$ & $\mathrm{H}$ & $\mathrm{OCH}_{3}$ & $A_{2}$ & 11.0 \\
\hline
\end{tabular}

SARs study of $\beta$-secretase and acetylcholinesterase inhibitory activity

1. 5'-Geranylation enhanced the activity $(\mathbf{5 0 - 5 3}>\mathbf{8}, \mathbf{1 5}, \mathbf{4 6}, \mathbf{5 4}, \mathbf{5 5})$

2. 3,8-Diprenylation reduced the activity $(8,15,46,54,55<50,51)$

3. 3-Glycosylation reduced the activity $(20>34)$<smiles>[R]c1c(-c2ccc(O)cc2O)oc2c3c(cc(O)c2c1=O)OC(C)(CC)C=C3</smiles>

15: $\frac{\mathrm{R} \quad \mathrm{IC}_{50}}{A_{1} \text { Inactive }}$

54: $A_{12}$ Inactive

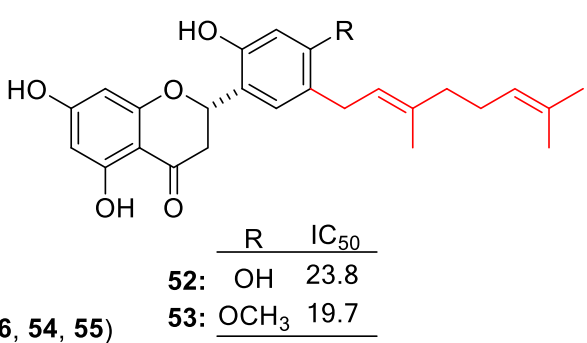<smiles>CC(C)=CC1Oc2cc(O)ccc2-c2oc3c4c(cc(O)c3c(=O)c21)OC(C)(C)C=C4</smiles><smiles>CC1(C)C=Cc2c(cc(O)c3c(=O)c4c(oc23)-c2ccc(O)cc2OC(C(C)(C)O)C4)O1</smiles>

55

Inactive

Fig. 5 Structures of compounds $\mathbf{8}, \mathbf{1 5}, \mathbf{2 0}, \mathbf{3 4}, \mathbf{4 6}$, and $\mathbf{5 0 - 5 5}$ (for the structure of $\boldsymbol{A}_{1}, \boldsymbol{A}_{2}$, and $\boldsymbol{A}_{\mathbf{1 2}}$ see Fig. 1) for SARs study of $\beta$-secretase and acetylcholinesterase inhibitory activity (the unit of $\mathrm{EC}_{50}$ and $\mathrm{IC}_{50}: \mu \mathrm{M}$ )

morusin (15), and 5,7,2',4'-tetrahydroxy-3-methoxyflavone (56) obtained from the wood of $M$. australis were evaluated [32]. On comparing their inhibitory activities, it was found that the prenyl units at $\mathrm{C}-7 \mathrm{might}$ be an active unit of prenyl flavonoids $\left(\mathbf{8}, \mathbf{1 5}\right.$ vs $\mathbf{5 6}$ with $\mathrm{IC}_{50}$ values at $14.0 \pm 1.0$, $10.1 \pm 0.8$, and $37.3 \pm 5.4 \mu \mathrm{M}$, respectively). In addition, on comparing the activities of compounds cathayanon $\mathrm{H}(\mathbf{5 7})$ and cathayanon I (58) isolated from the stem bark of $M$. cathayana, it suggested that $\mathrm{C}-2^{\prime}$ hydroxylation might lower the cytotoxicity [33]. Meanwhile, the configurations of C-2 and C-3 might affect the activity $(2 R 3 S>2 S 3 R)$ [cathayanin B (59) vs cathayanin C (60, inactivive)] of flavonols (Fig. 6).

For stilbenes and benzofurans from the wood of M. australis, the existence of isoprenyls could enhance the inhibitory activities obviously [mulberroside A (61) vs oxyresveratrol (62) with $\mathrm{IC}_{50}$ values at $6.9 \pm 0.7$ and $35.3 \pm 3.7 \mu \mathrm{M}$, respectively; moracin $\mathrm{C}(\mathbf{3 7})$ vs moracin $\mathrm{M}(\mathbf{3 9})$ with $\mathrm{IC}_{50}$ values at $8.7 \pm 0.3,24.8 \pm 0.0 \mu \mathrm{M}$, respectively] [32] (Fig. 6).

\section{Conclusions}

Morus alba has a long history of medicinal and edible usage in China. The relatively mature studies on its phytochemistry and pharmacology and clinical trials have led to enormous economic value [3].

On the basis of reports and reviews published, the SARs of $\alpha$-glucosidase, lipase, tyrosinase, $\beta$-secretase, and acetylcholinesterase, and cytotoxicity of compounds obtained from Morus genus plants have been summarized. Therefore, prenyl and hydroxyl substituted flavonoids compounds, benzofurans, stilbenes, and Diels-Alder adducts were found to possess significant bioactivities, which may provide some references for the seeking of effective substances with anti-diabetic, anti-obesity, neuroprotective and anti-cancer effects. 
<smiles>[R2]c1c(-c2ccc(O)cc2O)oc2c([R2])c(O)cc(O)c2c1=O</smiles>

$$
\begin{array}{cccc} 
& \mathrm{R}_{1} & \mathrm{R}_{2} & \mathrm{IC}_{50}(\mu \mathrm{M}) \\
\cline { 2 - 4 } \text { 8: } & A_{1} & A_{1} & 14.0 \pm 1.0 \\
\text { 56: } & \mathrm{OCH}_{3} & \mathrm{H} & 37.3 \pm 5.4 \\
\hline
\end{array}
$$<smiles>[R]c1c(O)cc(-c2cc3ccc(O)cc3o2)cc1O</smiles><smiles>CC(C)=CCc1c(-c2ccc(O)cc2O)oc2c3c(cc(O)c2c1=O)OC(C)(C)C=C3</smiles>

$15\left(\mathrm{IC}_{50}: 10.1 \pm 0.8 \mu \mathrm{M}\right)$

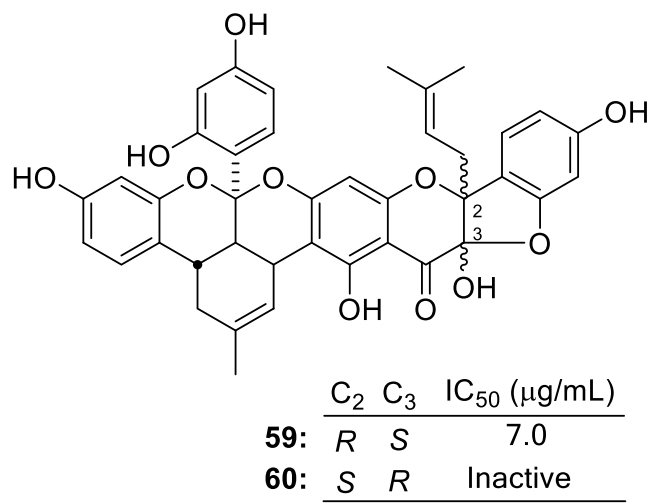<smiles>[R]c1c([C@@H]2Oc3cc(O)cc(O)c3C(=O)[C@@H]2O)cc(CC=C(C)C)c(O)c1[Y19]</smiles>

\begin{tabular}{llc} 
& $\mathrm{R}$ & $\mathrm{IC}_{50}(\mu \mathrm{g} / \mathrm{mL})$ \\
\cline { 2 - 3 } 57: & $\mathrm{H}$ & 6.7 \\
58: & $\mathrm{OH}$ & Inactive \\
\cline { 2 - 3 }
\end{tabular}

\section{SARs study of cytotoxicity}

1. Prenylation increased the cytotoxic properties $(8,15>56 ; 37>39 ; 61>62)$;

2. 2 '-OH lower the cytotoxicity $(58<57)$;

3. Configuration would effect the activity $(59>60)$

Fig. 6 Structures of compounds $8,15,37,39,56-62$ (for the structure of $A_{1}$ and $A_{2}$ see Fig. 1) for SARs study of cytotoxicity

Acknowledgements The research was supported by the Program of Important Drug Development Fund, Ministry of Science and Technology of China (2018ZX09735-002) and the National Natural Science Foundation of China (no. 81673688).

Open Access This article is licensed under a Creative Commons Attribution 4.0 International License, which permits use, sharing, adaptation, distribution and reproduction in any medium or format, as long as you give appropriate credit to the original author(s) and the source, provide a link to the Creative Commons licence, and indicate if changes were made. The images or other third party material in this article are included in the article's Creative Commons licence, unless indicated otherwise in a credit line to the material. If material is not included in the article's Creative Commons licence and your intended use is not permitted by statutory regulation or exceeds the permitted use, you will need to obtain permission directly from the copyright holder. To view a copy of this licence, visit http://creativecommons.org/licenses/by/4.0/.

\section{References}

1. Yang Y, Tan YX, Chen RY, Kang J (2014) The latest review on the polyphenols and their bioactivities of Chinese Morus plants. J Asian Nat Prod Res 16(6):690-702

2. Chan EW, Lye PY, Wong SK (2016) Phytochemistry, pharmacology, and clinical trials of Morus alba. Chin J Nat Med 14(1):17-30

3. Thaipitakwong T, Numhom S, Aramwit P (2018) Mulberry leaves and their potential effects against cardiometabolic risks: a review of chemical compositions, biological properties and clinical efficacy. Pharm Biol 56(1):109-118

4. Chaita E, Lambrinidis G, Cheimonidi C, Agalou A, Beis D, Trougakos I, Mikros E, Skaltsounis AL, Aligiannis N (2017) Antimelanogenic properties of Greek plants. A novel depigmenting agent from Morus alba wood. Molecules 22(4):E514

5. Kuk EB, Jo AR, Oh SI, Sohn HS, Seong SH, Roy A, Choi JS, Jung HA (2017) Anti-Alzheimer's disease activity of compounds from the root bark of Morus alba L. Arch Pharm Res 40(3):338-349

6. Mudra M, Ercan-Fang N, Zhong L, Furne J, Levitt M (2007) Influence of mulberry leaf extract on the blood glucose and breath hydrogen response to ingestion of $75 \mathrm{~g}$ sucrose by type 2 diabetic and control subjects. Diabetes Care 30(5):1272-1274

7. Kimura T, Nakagawa K, Kubota H, Kojima Y, Goto Y, Yamagishi K, Oita S, Oikawa S, Miyazawa T (2007) Food-grade mulberry powder enriched with 1-deoxynojirimycin suppresses the elevation of postprandial blood glucose in humans. J Agric Food Chem 55(14):5869-5874

8. Kojima Y, Kimura T, Nakagawa K, Asai A, Hasumi K, Oikawa S, Miyazawa T (2010) Effects of mulberry leaf extract rich in 1-deoxynojirimycin on blood lipid profiles in humans. J Clin Biochem Nutr 47(2):155-161

9. Andallu B, Suryakantham V, Srikanthi BL, Reddy GK (2001) Effect of mulberry Morus indica L. therapy on plasma and erythrocyte membrane lipids in patients with type 2 diabetes. Clin Chim Acta 314(1-2):47-53

10. Li XH, Xu LX, Wu P, Xie HH, Huang ZL, Ye WH, Wei XY (2009) Prenylflavonols from the leaves of Macaranga sampsonii. Chem Pharm Bull 57(5):495-498 
11. Hu X, Wu JW, Wang M, Yu MH, Zhao QS, Wang HY, Hou AJ (2012) 2-Arylbenzofuran, flavonoid, and tyrosinase inhibitory constituents of Morus yunnanensis. J Nat Prod 75(1):82-87

12. Ha MT, Seong SH, Nguyen TD, Cho WK, Ah KJ, Ma JY, Woo MH, Choi JS, Min BS (2018) Chalcone derivatives from the root bark of Morus alba L. act as inhibitors of PTP1B and $\alpha$-glucosidase. Phytochemistry $155: 114-125$

13. Ni G (2010) Studies on the chemical constituents and bioactivities of Acorus tatarinowii Schott and Morus cathayana. Graduation thesis of Ph.D. degree, Chinese Academy of Medical Sciences and Peking Union Medieal College, Beijing, China

14. Ahn E, Lee J, Jeon YH, Choi SW, Kim E (2017) Anti-diabetic effects of mulberry (Morus alba L.) branches and oxyresveratrol in streptozotocin-induced diabetic mice. Food Sci Biotechnol 26(6): 1693-1702

15. Zhang YL, Luo JG, Wan CX, Zhou ZB, Kong LY (2015) Four new flavonoids with $\alpha$-glucosidase inhibitory activities from Morus alba var. tatarica. Chem Biodivers 12(11):1768-1776

16. Yang ZZ, Wang YC, Wang Y, Zhang YF (2012) Bioassayguided screening and isolation of $\alpha$-glucosidase and tyrosinase inhibitors from leaves of Morus alba. Food Chem 131:617-625

17. Zhang YL, Luo JG, Wan CX, Zhou ZB, Kong LY (2014) Geranylated 2-arylbenzofurans from Morus alba var. tatarica and their $\alpha$-glucosidase and protein tyrosine phosphatase 1B inhibitory activities. Fitoterapia 92:116-126

18. Zeni ALB, Moreira TD, Dalmagro AP, Camargo A, Bini LA, Simionatto EL, Scharf DR (2017) Evaluation of phenolic compounds and lipid-lowering effect of Morus nigra leaves extract. An Acad Bras Cienc 89(4):2805-2815

19. Li HX, Jo E, Myung CS, Kim YH, Yang SY (2018) Lipolytic effect of compounds isolated from leaves of mulberry (Morus alba L.) in 3T3-L1 adipocytes. Nat Prod Res 32(16):1963-1966

20. Jeong JY, Jo YH, Kim SB, Liu Q, Lee JW, Mo EJ, Lee KYB, Hwang Y, Lee MK (2015) Pancreatic lipase inhibitory constituents from Morus alba leaves and optimization for extraction conditions. Bioorg Med Chem Lett 25(11):2269-2274

21. Ha MTL, Tran MH, Ah KJ, Jo KJ, Kim J, Kim WD, Cheon WJ, Woo MH, Ryu SH, Min BS (2016) Potential pancreatic lipase inhibitory activity of phenolic constituents from the root bark of Morus alba. Bioorg Med Chem Lett 26(12):2788-2794

22. Li HX, Park JU, Su XD, Kim KT, Kang JS, Kim YR, Kim YH, Yang SY (2018) Identification of anti-melanogenesis constituents from Morus alba L. leaves. Molecules 23(10):E2559
23. Koirala P, Seong SH, Zhou Y, Shrestha S, Jung HA, Choi JS (2018) Structure-activity relationship of the tyrosinase inhibitors kuwanon G, mulberrofuran G, and albanol B from Morus species: a kinetics and molecular docking study. Molecules 23(6):E1413

24. Shin NH, Ryu SY, Choi EJ, Kang SH, Chang IM, Min KR, Kim Y (1998) Oxyresveratrol as the potent inhibitor on dopa oxidase activity of mushroom tyrosinase. Biochem Biophs Res Commun 243(3):801-803

25. Zheng ZP, Cheng KW, Zhu Q, Wang XC, Lin ZX, Wang MF (2010) Tyrosinase inhibitory constituents from the roots of Morus nigra: a structure-activity relationship study. J Agric Food Chem 58(9):5368-5373

26. Ryu YB, Ha TJ, Curtis-Long MJ, Ryu HW, Gal SW, Park KH (2008) Inhibitory effects on mushroom tyrosinase by flavones from the stem barks of Morus lhou (S.) Koidz. J Enzyme Inhib Med Chem 23(6):922-930

27. Zheng ZP, Tan HY, Wang M (2012) Tyrosinase inhibition constituents from the roots of Morus australis. Fitoterapia 83(6): 1008-1013

28. Xia CL, Tang GH, Guo YQ, Xu YK, Huang ZS, Yin S (2019) Mulberry Diels-Alder-type adducts from Morus alba as multi-targeted agents for Alzheimer's disease. Phytochemistry 157:82-91

29. Cho JK, Ryu YB, Curtis-Long MJ, Kim JY, Kim D, Lee S, Lee WS, Park KH (2011) Inhibition and structural reliability of prenylated flavones from the stem bark of Morus lhou on $\beta$-secretase (BACE-1). Bioorg Med Chem Lett 21(10):2945-2948

30. Kim JY, Lee WS, Kim YS, Curtis-Long MJ, Lee BW, Ryu YB, Park KH (2011) Isolation of cholinesterase-inhibiting flavonoids from Morus lhou. J Agric Food Chem 59(9):4589-4596

31. Seo KH, Lee DY, Jeong RH, Lee DS, Kim YE, Hong EK, Kim YC, Baek NI (2015) Neuroprotective effect of prenylated arylbenzofuran and flavonoids from Morus alba fruits on glutamateinduced oxidative injury in HT22 hippocampal cells. J Med Food 18(4):403-408

32. Ferlinahayati SYM, Juliawaty LD, Achmad SA, Hakim EH, Takayama H, Said IM, Latip J (2008) Phenolic constituents from the wood of Morus australis with cytotoxic activity. Z Naturforsch C 63(1-2):35-39

33. Ni G, Zhang QJ, Wang YH, Chen RY, Zheng ZF, Yu DQ (2010) Chemical constituents of the stem bark of Morus cathayana. J Asian Nat Prod Res 12(6):505-515

Publisher's Note Springer Nature remains neutral with regard to jurisdictional claims in published maps and institutional affiliations.

\title{
Affiliations
}

\author{
Jiejing Yan ${ }^{1} \cdot$ Jingya Ruan ${ }^{1} \cdot$ Peijian Huang ${ }^{2} \cdot$ Fan Sun $^{1} \cdot$ Dandan Zheng $^{2} \cdot$ Yi Zhang $^{1,2} \cdot$ Tao Wang $^{1,2}$ \\ Yi Zhang \\ zhwwxzh@tjutcm.edu.cn \\ Tao Wang \\ wangtao@tjutcm.edu.cn \\ 2 Tianjin Key Laboratory of TCM Chemistry and Analysis, \\ Institute of Traditional Chinese Medicine, Tianjin University \\ of Traditional Chinese Medicine, 312 Anshanxi Road, \\ Nankai District, Tianjin 300193, China
}

1 Tianjin State Key Laboratory of Modern Chinese Medicine, Tianjin University of Traditional Chinese Medicine, 312 Anshanxi Road, Nankai District, Tianjin 300193, China 